\title{
An Understanding the Pauline Christology Significance of Firstborn (Protokos) In The Light of Paschal Theology: Critical Evaluation on Colossian 1: 15-20
}

\author{
Halim Wiryadinata \\ Sekolah Tinggi Teologi Pelita Bangsa Jakarta \\ ketua@sttpb.ac.id
}

\begin{abstract}
Paul was claimed as the most controversial person in his theology. Many scholars said that he was influenced by Hellenistic Judaism in his theology; while others claimed it was affected of Jewish thinking.

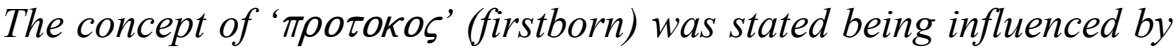
Hellenistic Judaism and did not imply the rest of New Testament Theology. Some said that firstborn in Colossian 1: 15-20 was a hymn in praise of Christ, while others would say that firstborn in the Hymn Christology is congenial, but not identical with Paul's theology. This research aimed to show the concept of firstborn as the main window showed Pauline Christology significance in the light of Paschal theology. The methods used in this research were descriptive and biblical text analysis. The conclusion of this research is that the death of Christ is the main point to see how firstborn of all creation not counted as ontological in meaning, but it has the power to show the readers about Pauline Christology. The firstborn of all creation is seen in the context of redemptive history and bring the audience to see how powerful the title to see Pauline Christology.
\end{abstract}

Article History

Submit:

16 Februari 2018

Accept:

06 April 2018

Publish:

11 April 2018

\author{
Keywords: \\ Colossian; \\ firstborn; \\ protokos; \\ Paschal; Pauline \\ theology
}

\section{Introduction}

New Testament scholars have claimed that the Apostle Paul was the creator of Christianity. Then, they thought that Paul has changed the original message of Jesus and emerged the teaching of Jesus with Paul's influence in the Hellenistic background. In other words, most of New Testament scholars in the past hundred years claimed that Paul Hellenised the Jewish message and went on saying that the Gospels were written by Christian communities, who invented the stories about Jesus to teach Gentiles believers.

The above presuppositions, however, are not right, because we would like to demonstrate that the Apostle Paul is the very faithful person to the teaching of Jesus Christ. 
Tom Holland insists strongly when he says, “... the teaching of Jesus and Paul has clear links with the Old Testament." If our assumption is right that the Old Testament theology plays an important role in Pauline Christology, then we would like to present the firstborn is the central point of Paul Christology. ${ }^{2}$ This points a contradict the headings of the prominent titles of Pauline Christology such as Lord, Son of God, Saviour and Adam and Wisdom. ${ }^{3}$ Therefore, our investigation on the terminology of Firstborn is a very important breakthrough to get the idea of Pauline Christology.

According to the Old Testament theology, there are three roles of the firstborn, which rejects the idea of ontological interpretation, but it shows that Christ acts as the firstborn. The three roles of firstborn are: Firstly, a responsibility that falls upon the shoulder of redeemer is to secure revenge for his family. When a member of the family is murdered, then the redeemer must revenge on the exact blood on the person. (Gen. 4: 14-15; Num. 35: 22-29; Deut. 19:4-10). In the New Testament Christ is presenting as taking the responsibility. (Luke 1: 68-79 2 Thess. 1: 6-9).

Secondly, the next role of firstborn is to secure the property that has been lost to the family through debt. This picture can be seen from the story of Ruth. (Ruth 4:4). In the New Testament Christ recovers the Kingdom of Heaven for those who are in sin. (Col. 1: 13-14; Heb. 9:15; Rev. 21:1-4). Thirdly, the role of firstborn is to fulfill the law of levirate. This law is asked the redeemer to predict the window in the family. (Deut. 25: 5-10; Ruth 3:13; 4:1-8). In the New Testament, Christ takes the church to himself and acts as her husband. (Jon 3: 2829; Romans 7: 1-4).

This leads to Jeremias ${ }^{4}$ to point out that the idea of Passover theme is very extensively used by the Old and New Testament in the mind of the early church. However, he did not show and explore the firstborn title in the light of the Passover theme. This missing link has been added by Preiss when he sees that there is much emphasis on the Paschal theme, "The totality of the events of the Exodus centring on the Passover together with its associated ideas occupied a dominant position in Christian soteriological thought in the New Testament period, especially as Jesus Himself has instituted the Eucharist in a distinctively Paschal setting." If Jeremias and Preiss are right in their research, then the title of firstborn should be

\footnotetext{
${ }^{1}$ Tom Holland, Contours of Pauline Theology (Scotland: Mentor, 2004), 12.

${ }^{2}$ This is the main point of this essay, to be explored at the next chapter.

${ }^{3}$ Gerald Hawthorne, Raplh Martin, and Daniel G Reid, Dictionary of Paul and His Letters (England: IVP, 1993), 100.

4Joachim Jeremias, "This Is My Body," The Expository Times 83, no. 7 (April 24, 1972): 196-203, accessed March 22, 2018, http://journals.sagepub.com/doi/10.1177/001452467208300702.

${ }^{5}$ Preiss, Life in Christ (London: SCM, 1957), 90.
} 
seen in the light of paschal setting to get the coherence of Paul's Christology. Moreover, it is the best way to look at the next section of Paul, Jesus and Old Testament.

The main purpose of this work is to contribute something towards a biblical theology, especially Pauline theology for Christological significance by showing the root of problems. Ignorance is not helpful, and it is, therefore, not acceptable that people denied an understanding of the truth. However, the Christian scholars, in some way or another, seem to unravel the importance of the terminology of the firstborn title. Hence, this research aims to help to contribute, in some way, to provide the final destination of the terminology for the Christological significance in the New Testament Theology.

\section{Methodology}

The methodology used in this research took the form of a critical analysis of the recent study, as a way of accessing the root problems in the terminology of the firstborn title. This analysis shall be limited to the period early Christology to the present analysis (for reasons of space). By conducting this analysis, we shall seek to ascertain the extent to which blame can be laid at the door of Biblical Theology. In other words, the analysis shall proceed on a descriptive basis. The analysis of the opinions of the other scholars is taken as a locus for developing our argument. It is anticipated that this shall enable us to propose some ideas to work towards the answer to the research.

For that purpose, the mindset of 'corporate identity' will be presupposed throughout this research. This, however, does not mean that the individual identity is not important to the research. Both individual and corporate identities certainly give a sense of one's own security and belonging, rootedness, and direction, which is basic to human existence.

Thus, the structure of this research begins with the statement of the issues to do the background of the Firstborn. From here the argument is appraised in the light of a critical analysis of the basic problems. Finally, after looking at a possible solution from the terminology of the Firstborn title, the result of the investigation are applied to the Biblical Theology.

\section{Analysis}

\section{Paul, Jesus and Old Testament}

This section is to show how the integration between Paul, Jesus, and Old Testament tight together to interpret our investigation on firstborn. In the beginning, was said if the Apostle Paul tried to change the original message of Jesus, the question will be good to be 
delivered: Do Christian people follow Jesus or do they follow Paul? Here is the methodology needs to be considered and answered before we go on arguing about Firstborn.

Mark Nanos said, "Where New Testament scholarship is concerned, the literature can now be read as Jewish correspondence, written by and for Jews and Gentiles concerned with the Jewish context of their faith in Jesus as the Jewish Messiah. Simply put, we can now read the New Testament as a Jewish book." "If Nanos is right in his opinion, then the New Testament should be seen from the perspective of Jewish context. The early church also never abandons the Jewishness message in explaining how the apostles communicated the Gospel of Jesus to the audiences. Then, it leads us to ask: What is the Jewish message?

Holland insists very strong when he says, "It will become clear that the evidence powerfully suggests that the teaching of Jesus and Paul has clear links with the Old Testament." ${ }^{, 7} \mathrm{He}$ argues in details that the apostle Paul needs to be understood in the line of the Old Testament, and the model of Passover is a type of the work of Jesus. In his concluding research, was said that the Apostle Paul had never left the teaching of Jesus and the Old Testament. By looking at the Old Testament, people can see the nature of Jesus and Paul links in understanding the nature of Paul's theology. ${ }^{8}$

If Tom Holland and Nanos are accepted for their presupposition, then we should demonstrate how the Apostle Paul is really under the influence of the Old Testament in his theology. The quotations of the Old Testament play a very important role; how the Apostle Paul depends upon the Old Testament. Paul actually not only quotes from the book of Isaiah for many more times than all other prophets put together, but he tries to build up the prophet's (Isaiah) as his theological scaffolding. We, however, should follow the Isaianic text in which Paul has cited. Here's some of what Paul might cite from Isaiah:

- "As it is written, 'God's name is blasphemed among the Gentiles because of you" (Romans 2: 24; Isaiah 52:5, LXX).

- "Their feet are swift to shed blood: ruin and misery mark their paths and the way of peace they have not known" (Romans 3: 15-17; Isaiah 59: 7-8).

- "Isaiah cries out concerning Israel: "Though the number of the Israelites should be like the sand by the sea, only the remnant will be saved. For the Lord will carry out his sentence on earth with speed and finality." It is just as Isaiah has said previously" (Romans 9: 27-28); Isaiah 10: 22:23, LXX).

\footnotetext{
${ }^{6}$ Mark Nanos, The Mystery of Romans (England: Fortress Press, 1997), 7.

${ }^{7}$ Holland, Contours of Pauline Theology, 12.

${ }^{8}$ Ibid, 13 .
} 
- "Just as Isaiah said previously, 'Unless the Lord Almighty had left us, descendants, we would become like Sodom, and we would have been like Gomorrah" (Romans: 9:29; Isaiah 9:1, LXX).

- "As it is written, 'See, I lay in Zion a stone that causes men to stumble and a rock that makes them fall' (Romans9:33a; Isaiah 8:14).

- 'and 'the one who trusts in him will never put to shame' (Romans 9:33; Isaiah 28:16, LXX).

- "As the Scriptures says, "He who believes in him will not be disappointed" (Romans 10:11; Isaiah 52:7, LXX).

- "As it is written, "How beautiful are the feet of those who bring good news" (Romans10:15; Isaiah 52:7).

- "For Isaiah says, "Lord, who has believed our message?" (Romans 10: 16; Isaiah 53:1, LXX).

- "And Isaiah boldly says, "I was found by those who did not seek me; I revealed myself to those who did not ask for me." (Romans 10:20; Isaiah 29:10, LXX).

- "What then? What Israel sought so earnestly it did not obtain, but the elect did. The others were hardened, as it is written: "God gave them a spirit of stupor, eyes so that they could not see and ears so that they could not hear, to this very day." (Romans 11:7-8; Isaiah 29:10, LXX).

- "And so all Israel will be saved, as it is written: "The deliverer will come from Zion; he will turn godlessness away from Jacob. And this is my covenant with them when I take away their sins." (Romans 11:26-27; Isaiah 59: 20-21, LXX).

- "Who has known the mind of the Lord? Or who has been his counselor?" (Romans11:34; Isaiah 59:20-21, LXX).

- "It is written: "'As surely as I live,' says the Lord, 'every knee will bow before me; every tongue will confess to God.'" (Romans 14:11; Isaiah 40: 13; Isaiah 45:23, LXX).

- "And again, Isaiah says, "The Root of Jesse will spring up, one who will arise to rule over the nations; the Gentiles will hope in him." (Romans 15: 12; Isaiah 11:10, LXX).

- "Rather, as it is written: "Those who were not told about him will see, and those who have not heard will understand."(Romans 15:21; Isaiah 52:15, LXX).

This dependency of Paul's writing on the book of Isaiah has a clear picture of how the Apostle Paul tries to build up his argument in the Old Testament area. In other words, Paul's 
dependence on Isaiah particularly also applies to the Old Testament as a whole. Far beyond his dependency, it is assumed that his exposition and reasoning of the good news of Jesus was arranged around the structure to convey the message that Jesus is the fulfillment of all the prophets had been saying. The dependency of the Old Testament of the above passages is very clear of the salvation history in saving of humanity. Therefore, our methodology seems to be proved that Paul, Jesus, and the Old Testament have a tight together and they cannot be separated. ${ }^{9}$

We also argue that New Testament scholars seem to be wrong when they claim that Paul has left the original message of Jesus Christ. It leads us to see that Paul is not the innovator of Christian doctrine, but he is the faithful servant of the Lord Jesus Christ as the ambassador who is very consistent delivering his Master's message to the Gentiles. He also stays very faithful in the framework of the Old Testament and presses the promises for the Gentiles.

\section{Firstborn and Paschal Setting}

The setting of new methodology in interpreting New Testament especially Pauline theology needs to be redefined. Osborne states, "Christological theory is in the process of a paradigm shift in methodology." 10 N. T. Wright also insists strongly, "Today there is a tacit agreement that the study of titles is not the way to proceed-even to the extent of some leading Jesus-scholars relegating them to the margin of their inquiries." ${ }^{11}$ It seems that there a new shift to recognize the Christological material. Therefore, it becomes clear that the New Testament church is interested in soteriology and not in ontology, where New Testament and Old Testament the idea of redemption and creation are inseparable. Therefore, it seems to be right to say that Pauline Christological material does not come from the interaction with Hellenistic philosophy, but it depends heavily on the Old Testament context, especially Jewish mindset.

From what it has been said above, it leads us to see the Passover narrative, where the firstborn is designated by Yahweh to represent the family. Here, the idea of Firstborn as a representative of the family plays an important role. It is bound up with the family's deliverance from the angel of death. The important point of the Firstborn is that it is not the family as a whole by what the lamb represented, but the firstborn. The firstborn's life is

${ }^{9}$ L W Hurtado, "New Testament Studies in the 20th Century," Religion 39, no. 1 (2009): 43-57, http://dx.doi.org/10.1016/j.religion.2008.03.006.

${ }^{10}$ Grant R. Osborne, "Christology and New Testament Hermeneutics: A Survey of the Discussion," in Semia 30, 1984, 49

${ }^{11}$ N.T. Wright, Jesus and the Victory of God (England: SPCK, 1997), 614. 
threatened because he represented the family. In the New Testament, Christ is the Lamb of God, and He is our Passover, who is the representative of his family. Christ died as the paschal lamb and also he was the firstborn. Therefore, the term protokos ${ }^{12}$ cannot be seen from the ontological point of view, but it should be understood from the perspective of redemptive history. In other words, Christ is not only as the firstborn, but he acts as the firstborn.

For Paul, it seems that redemption, like Fall, has a cosmic dimension. In Paul's letter to the Romans, Romans 8 shows the whole universe is waiting for restoration and will happen in the death of Christ as the climax of the redemptive work. If this is so, then the significance of the death of Christ is not only for His own family but also for the universe in the tragedy of the fall. Therefore, Christ is the firstborn of all creation (Colossians 1: 15).

Yahuda points out that the death of firstborn in the Passover is very significance for the entire of firstborn. ${ }^{13} \mathrm{He}$ sees that the firstborn son of Pharaoh had the same rank with his father because he had a title 'Sa-Ra-en-Khetef,' i.e. 'the son of Ra from his body., ${ }^{14}$ Yahuda argues the significance of the death of the firstborn is "To defy the mighty gods of Egypt, to expose their importance to protect the offspring of the "Son of $\mathrm{Ra}^{\prime} . " 15$ If this is so, the question arises: why was it the firstborn, and not the father, who represented the family?

Jeremias argues against Yahuda's idea of firstborn by saying that Paul uses the last Adam imagery to fulfill the role of firstborn. He states, "With his Adam/Christ antithesis Paul expresses the same thought as underlines Jesus' self-description as bar Nasha, namely, that Jesus is the firstborn of the new creation of God. Like Adam, he stands at the of the aion mellon as the initiator of the perfect redeemed creation of God." ${ }^{16}$ Ridderbos support Jeremias when he claims that not only the firstborn title links to Adamic imagery, but also it is the cornerstone of Paul's Christology. ${ }^{17} \mathrm{He}$ comments, "In other words, from Christ's significance as the Second Adam all the categories are derived which further defined his significance as the firstborn of every creature."18

${ }^{12}$ Michaelis commented on the etymology of the Hebrew bekor (firstborn) that it "neither connected with the Hebrew words for 'to give birth' - it can be used for fruits etc. as well. Nor is it related to the words for 'one', 'first', nor the similar word for 'head', 'chief' - to the concept which it was designated to express there did not necessarily belong a comparison with other things of the same kind, since the first might also be the only one. (See Michaels, "Theological Dictionary of New Testament," in Theological Dictionary of New Testament, ed. Gerhard Friedrich and Gerhard Kittel, V. (Michigan: Erdmands, n.d.), 873.

${ }^{13}$ A. S. Yahuda, The Accuracy of the Bible (England: William Heineman, 1934), 85-86..

${ }^{14}$ Ibid.

${ }^{15}$ Ibid.

${ }^{16}$ Jeremias, "This Is My Body."

${ }^{17}$ Paul Ridderbos, Herman., An Outline of His Theology (Chicago: William Eedermans, 1975), 84.

${ }^{18}$ Ibid. 
Davies $^{19}$ tries to argue that the firstborn in Colossians $1: 15$ is a direct reference to Proverbs 8:22 when he is also supported by C. F. Burney ${ }^{20}$ saying, "The Lord possessed me at the beginning of his work, before his deeds of old." Burney argues the term reshith in Proverbs 8: 22 is used in rabbinic Judaism as the key of bereshith that begins the Hebrew Bible. Then, the word bereshith of Genesis 1 is correspondingly interpreted as meaning by wisdom. ${ }^{21}$ If this is so, then Davies and Burney try to argue that the word firstborn and wisdom are synonymous. However, the question should be asked: Are they synonymous? Therefore, it leads us to see how the Apostle Paul uses the term firstborn in Colossians.

\section{A Critical Evaluation of Firstborn and the Colossian Hymn}

This is not a point of not discussing about the author of the Colossian, because they are many New Testament scholars, who discussed about the authorship. However, those who accept Pauline as the authorship of Colossian will be divided into three groups. The first, a group which claim that Colossian 1:15-20 is an independent composition of the early church as a hymn in praise of Christ. Schweizer insists that this hymn is congenial to Paul, but not identical with his theology. ${ }^{22}$ The second group claims that Paul quotes hymn as a confessional statement. They think that Paul tries to secure a common agreement with his theme of the letter. ${ }^{23}$ The third group claims that there is no reason to deny Pauline authorship of the hymn. ${ }^{24}$

The debate about hymn should be based on the word of Firstborn in Colossian 1: 15320. Some people see that firstborn has something to do with hierarchical, but others see it to be ontological. However, James Dunn can distinguish very clearly about the term 'firstborn'. He insists strongly, "The antecedent for the use of the word firstborn in relation to creation is most obviously Wisdom." 25 Casey supports the idea of James Dunn by saying, "The inclusion

\footnotetext{
${ }^{19}$ W. D. Davies, Paul and Rabbinic Judaism (England: SPCK, 1955).

${ }^{20}$ C. F. BURNEY, "CHRIST AS THE APXH OF CREATION," The Journal of Theological Studies, Volume os-XXVII, Issue 106, 1 Vol 27, no. 106 (1926): 160-177, accessed March 21, 2018, https://watermark.silverchair.com/160.pdf?token=AQECAHi208BE49Ooan9kkhW_Ercy7Dm3ZL_9Cf3qfKAc4 85ysgAAAbUwggGxBgkqhkiG9w0BBwagggGiMIIBngIBADCCAZcGCSqGSIb3DQEHATAeBglghkgBZQM EAS4wEQQM_-MceAEFy_2QcN3mAgEQgIIBaDe0xgG4uryYhbTeC_FtHJmLVeB-Ecnf4ZdkSqAbngsxviGn22. ${ }^{21}$ Ibid.

${ }^{22}$ Eduard Schweizer, “Colossians 1: 15-20 Eduard Schweizer,” Review \& Expositor 87, no. 1 (February 22, 1990): 97-104, accessed March 22, 2018, http://journals.sagepub.com/doi/10.1177/003463739008700108

${ }^{23}$ Benjamin Edsall and Jennifer R. Strawbridge, “The Songs We Used to Sing? Hymn 'Traditions' and Reception in Pauline Letters," Journal for the Study of the New Testament 37, no. 3 (March 7, 2015): 290-311, accessed March 22, 2018, http://journals.sagepub.com/doi/10.1177/0142064X14567054.

${ }^{24}$ Nijay Gupta, "What Is in a Name? The Hermeneutics of Authorship Analysis Concerning Colossians," Currents in Biblical Research 11, no. 2 (February 17, 2013): 196-217, accessed March 22, 2018, http://journals.sagepub.com/doi/10.1177/1476993X12439885.

${ }^{25}$ James Dunn, The Epistle to the Colossians and Philemon (USA: Paternoster, 1996), 90.
} 
of a larger number of educated men had also forced attention on philosophical problems with which Palestinian Judaism was not concerned...introduced ways of thinking which we foreign to all but the Hellenistic Jewish mind...Nobody seems to be in doubt that Old Testament and later Jewish Wisdom speculation has provided a great number of the motifs and even vocabulary.",26

Vawter sees that the vocabulary of Colossians 1: 15-20 is based on Old Testament Wisdom vocabulary and argues, "But only some artificial sort of way can personifiedWisdom ideas be seen as the model for the portrayal of a cosmic redeemer. "27 Burney goes on to say that the hymn is similar to a Rabbinic Midrash in which Proverbs 8 is used to interpret Genesis $1 .^{28}$ Therefore, the idea of Wisdom Christology is very strongly in interpreting 'firstborn of all creation'. This leads us to see how Martin argues favorable, "Nothing in the teaching on Wisdom adumbrates the theme of redemption, whether cosmic or personal. ${ }^{, 29}$ If this is true, the Klijn sees the language of Colossian 1: 12-14 to be reflecting the LXX description of Isaiah 63: 15-19. ${ }^{30}$

From what it has been said above, it leads us to see that the hymn Christology in Colossian 1: 15-20 should be understood in the redemptive context or soteriology. In the redemptive context, we cannot be far away from the idea of the death of Christ. In other words, calling Christ the firstborn of all creation, Paul is attributing to the death of Christ. His death has achieved the redemption of the whole creation. It seems that cosmic redemption is not a minor theme, but it is the heart of the hymn.

If we look at the book of Isaiah, it is apparently has a prophecy that the redeemer will bring about the redemption not only from Israel's distress but for the whole of creation under the curse (Is. 55: 12-13; 65: 17-25). Isaiah has predicted that the creation itself will be renewed when the children of God will be delivered from their captivity. This is the link to the Paschal imagery when the language of exaltation for Christ plays an important role in Colossian 1: 15-25. Bedale pointed out that the word kephale (head) did not mean the head of

${ }^{26}$ R. P. CASEY, “THE EARLIEST CHRISTOLOGIES,” The Journal of Theological Studies IX, no. 2 (October 1, 1958): 253-277, accessed March 22, 2018, https://academic.oup.com/jts/articlelookup/doi/10.1093/jts/IX.2.253.

${ }^{27}$ Bruce Vawter, "The Colossians Hymn and the Principles of Redaction," in $C B Q 33,1971,62-81$.

${ }^{28}$ C. F. BURNEY, "CHRIST AS THE APXH OF CREATION." 48.

${ }^{29}$ R. P Martin, Colossians: The Church's Lord and the Christian's Liberty (USA: Paternoster, 1972),

${ }^{30}$ A. F. J. Klijn, “The Study of Jewish Christianity,” New Testament Studies 20, no. 4 (July 5, 1974): 419, accessed April 2, 2018, http://www.journals.cambridge.org/abstract_S0028688500012248. 
a community, otherwise it has the same meaning as firstborn. ${ }^{31}$ It means the word of 'head' is equal to the firstborn; then, it showed a very clear link between firstborn and redemption.

The reference to Christ as the image of invisible God is not ontological in meaning, but it has something to do with the rest of theological scaffolding of Pauline theology. It is, actually, Adamic imagery, which is referring to the role of Christ as the representative of Yahweh. It is very obvious that there is no creature on earth can redeem creation unless God Himself. In the Old Testament and New Testament, they are very clear to present only Creator, the Lord, who can do this. The prophecy of the Old Testament has presented that the great Passover events are celebrated by the Jewish King (2 Chor. 30: 1-24; 35: 1-19; Eze. 45: 22ff). In Ezekiel, the king is to be the main figure in eschatological celebration of the Passover. ${ }^{32}$ This also can be seen from the Gospel writers in the way they emphasize that Jesus died in the context of the Passover as King of the Jews.

The cross message, however, is central of victory that Christ has achieved over all of His opponents. Paul has confirmed that firstborn should be interpreted from the context of redemption. If this is so, then firstborn of all creation is to stress the meaning of Jesus as the Passover. Bowman also comments, "The death of the firstborn in Mark's Christian Jewish Haggadah of the Passover achieves the deliverance of the people enslaved to the Law and the Temple, yes and from the Romans too - but the deliverance is not wrought by the death of firstborn of the Egyptians, not even the death of Pharaoh's firstborn, nor at the price of the foreign oppressor, but by the death of the Saviour Himself." 33

Finally, Passover seems to mold the Apostle Paul in using cultic thinking and form his understanding on Paul's Christology. In other words, when the Apostle Paul develops his own Christology, then his mind was set up by his understanding about the firstborn. In other words, the central character in the Passover is the firstborn, and this description is applied to Christ. The representative idea is also very important because the firstborn applies the idea of whole creation to be restored.

\section{Conclusion}

After the investigation of the idea of firstborn, we could see the conclusion of the research. Some of the New Testament scholars seem to be wrong when they see only the titles

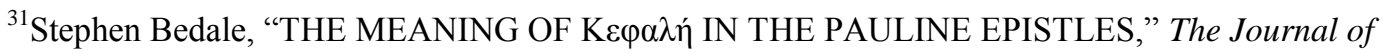
Theological Studies V, no. 2 (1954): 211-215, accessed March 22, 2018, https://academic.oup.com/jts/articlelookup/doi/10.1093/jts/V.2.211.

${ }^{32}$ Holland, Contours of Pauline Theology.

${ }^{33}$ J. Bowman, The Gospel of Mark: The New Christian Jewish Passover Haggadah (USA: E J Bril, 1965), 106-108.
} 
of Pauline Christology, and they have left out the terminology of protokos. Some of them claimed that Paul has changed the meaning of Jesus' message and modified it in the light of the Hellenistic Judaism.

However, our new methodology, which is based on Paul, Jesus, and the Old Testament, is very powerful to see how the Apostle Paul plays the word firstborn very important to see bring the idea of cultic language. Paul has never left his own idea of Isaiah dependency on Passover idea to represent Jesus. In other words, Paul is a very faithful servant to present Jesus in the light of the Old Testament theology.

Firstborn is seen in the light of Passover language and redemptive history; then it has a powerful message that Colossians tries to convey. If Jesus is the firstborn of creation, then he brings the idea of corporately as the whole body of His. The sentence 'He is the firstborn of creation' applies how the Lord redeemed the mankind to His own purpose. Therefore, Jesus is the firstborn of all creation means that He is the firstborn who bought back His own into His possession.

\section{References}

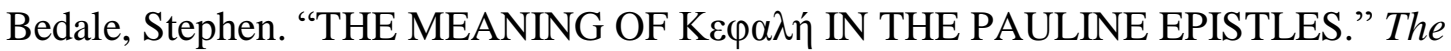
Journal of Theological Studies V, no. 2 (1954): 211-215. Accessed March 22, 2018. https://academic.oup.com/jts/article-lookup/doi/10.1093/jts/V.2.211.

Bowman, J. The Gospel of Mark: The New Christian Jewish Passover Haggadah. USA: E J Bril, 1965.

C. F. BURNEY. "CHRIST AS THE APXH OF CREATION.” The Journal of Theological Studies, Volume os-XXVII, Issue 106, 1 Vol 27, no. 106 (1926): 160-177. Accessed March 21, 2018.

https://watermark.silverchair.com/160.pdf?token=AQECAHi208BE49Ooan9kkhW_Erc y7Dm3ZL_9Cf3qfKAc485ysgAAAbUwggGxBgkqhkiG9w0BBwagggGiMIIBngIBAD CCAZcGCSqGSIb3DQEHATAeBglghkgBZQMEAS4wEQQM_MceAEFy_2QcN3mAgEQgIIBaDe0xgG4uryYhbTeC_FtHJmLVeB-Ecnf4ZdkSqAbngSxviGn22.

CASEY, R. P. “THE EARLIEST CHRISTOLOGIES." The Journal of Theological Studies

IX, no. 2 (October 1, 1958): 253-277. Accessed March 22, 2018.

https://academic.oup.com/jts/article-lookup/doi/10.1093/jts/IX.2.253.

Davies, W. D. Paul and Rabbinic Judaism. England: SPCK, 1955.

Dunn, James. The Epistle to the Colossians and Philemon. USA: Paternoster, 1996.

Edsall, Benjamin, and Jennifer R. Strawbridge. "The Songs We Used to Sing? Hymn 'Traditions' and Reception in Pauline Letters." Journal for the Study of the New Testament 37, no. 3 (March 7, 2015): 290-311. Accessed March 22, 2018. http://journals.sagepub.com/doi/10.1177/0142064X14567054.

Gupta, Nijay. "What Is in a Name? The Hermeneutics of Authorship Analysis Concerning Colossians." Currents in Biblical Research 11, no. 2 (February 17, 2013): 196-217. Accessed March 22, 2018. http://journals.sagepub.com/doi/10.1177/1476993X12439885. 
Hawthorne, Gerald, Raplh Martin, and Daniel G Reid. Dictionary of Paul and His Letters. England: IVP, 1993.

Holland, Tom. Contours of Pauline Theology. Scotland: Mentor, 2004.

Hurtado, L W. "New Testament Studies in the 20th Century." Religion 39, no. 1 (2009): 4357. http://dx.doi.org/10.1016/j.religion.2008.03.006.

Jeremias, Joachim. "This Is My Body." The Expository Times 83, no. 7 (April 24, 1972): 196-203. Accessed March 22, 2018. http://journals.sagepub.com/doi/10.1177/001452467208300702.

Klijn, A. F. J. "The Study of Jewish Christianity." New Testament Studies 20, no. 4 (July 5, 1974): 419. Accessed April 2, 2018. http://www.journals.cambridge.org/abstract_S0028688500012248.

Martin, R. P. Colossians: The Church's Lord and the Christian's Liberty. USA: Paternoster, 1972.

Michaels. "Theological Dictionary of New Testament." In Theological Dictionary of New Testament, edited by Gerhard Friedrich and Gerhard Kittel. V. Michigan: Erdmands, n.d.

Nanos, Mark. The Mystery of Romans. England: Fortress Press, 1997.

Osborne, Grant R. "Christology and New Testament Hermeneutics: A Survey of the Discussion." In Semia 30, 1984.

Preiss. Life in Christ. London: SCM, 1957.

Ridderbos, Herman., Paul. An Outline of His Theology. Chicago: William Eedermans, 1975.

Schweizer, Eduard. "Colossians 1: 15-20 Eduard Schweizer." Review \& Expositor 87, no. 1 (February 22, 1990): 97-104. Accessed March 22, 2018. http://journals.sagepub.com/doi/10.1177/003463739008700108.

Vawter, Bruce. "The Colossians Hymn and the Principles of Redaction." In $C B Q 33,62-81$, 1971.

Wright, N.T. Jesus and the Victory of God. England: SPCK, 1997.

Yahuda, A. S. The Accuracy of the Bible. England: William Heineman, 1934. 